\title{
Association among depression, cognitive impairment and executive dysfunction after stroke
}

\author{
Luisa Terroni ${ }^{1}$, Matildes F.M. Sobreiro ${ }^{1}$, Adriana B. Conforto², Carla C. Adda ${ }^{3}$, \\ Valeri D. Guajardo ${ }^{1,3}$, Mara Cristina S. de Lucia ${ }^{3}$, Renério Fráguas ${ }^{1}$
}

\begin{abstract}
The relationship between depression and cognitive impairment, frequent after stroke, is complex and has not been sufficiently elucidated. Objective: To review the relationship between post-stroke depression and cognitive impairment. Methods: We performed a PubMed database search spanning the last ten years, using the terms post-stroke depression, cognitive dysfunction, cognitive impairment and neuropsychological tests. Our target studies were original quantitative studies that investigated the relationship between post-stroke depression (PSD) and cognitive impairment in stroke patients. Articles published in English, Spanish, Italian and Portuguese were considered. Selection criteria were the use of neuropsychological tests to assess cognitive function, and of either instruments to diagnose major depression, or scales to assess depressive symptoms, within the first three months after stroke. Results: Six original quantitative studies fulfilled the criteria. The prevalence of PSD within the first three months after stroke ranged from $22 \%$ to $31 \%$. Incidence ranged from $25 \%$ to $27 \%$ and was evaluated in only two studies. PSD was associated with increased cognitive impairment. Cognitive impairment was reported in $35.2 \%$ to $87 \%$ of the patients. Post-stroke cognitive deficits were reported mostly in executive function, memory, language, and speed of processing. Conclusion: Executive dysfunction and depression occur in stroke survivors, are frequently coexistent, and also associated with worse stroke prognosis. Healthcare professionals need to address and provide adequate treatment for depression and executive dysfunctions in stroke patients early in the first three months after stroke. Future studies should evaluate the efficacy of programs evaluating the early detection and treatment of PSD and executive dysfunction in stroke survivors.
\end{abstract}

Key words: stroke, depression, cognition impairment, cognition, executive function, dysfunction, neuropsychological assessment.

ASSOCIAÇÃO ENTRE DEPRESSÃO, COMPROMETIMENTO COGNITIVO E DISFUNÇÃO EXECUTIVA APÓS ACIDENTE VASCULAR CEREBRAL RESUMO. A depressão e o déficit cognitivo são frequentes após 0 acidente vascular cerebral. A relação entre as duas condições é complexa e não tem sido suficientemente elucidada. Objetivo: Fazer uma revisão da relação entre a depressão pós-AVC e prejuízo cognitivo. Métodos: Foi realizada uma pesquisa no banco de dados PubMed nos últimos dez anos. Nosso foco foi estudos quantitativos originais que investigaram a relação entre depressão e comprometimento cognitivo em pacientes com AVC. Os termos depressão, disfunção cognitiva, comprometimento cognitivo e testes neuropsicológicos foram usados para pesquisa. Foram considerados artigos publicados em Inglês, Espanhol, Italiano e Português. Os critérios de seleção foram o uso de testes neuropsicológicos para avaliar a função cognitiva com também o uso de instrumentos para diagnosticar a depressão maior ou escalas para avaliar sintomas depressivos nos primeiros três meses após o AVC. Resultados: Seis estudos quantitativos originais preencheram os critérios de seleção. A prevalência de depressão pósAVC nos primeiros três meses após o AVC variou de $22 \%$ a $31 \%$. A incidência de depressão pós-AVC variou de $25 \%$ a $27 \%$ e foi avaliada apenas em dois estudos. A depressão pós-AVC esteve associada com comprometimento cognitivo mais acentuado. Disfunção cognitiva pós-AVC foi relatada em $35,2 \%$ a $87 \%$ dos pacientes. Déficits cognitivos pós-AVC foram encontrados principalmente em função executiva, memória, linguagem e velocidade de processamento. Conclusão: A disfunção executiva e a depressão ocorrem em pacientes de AVC, sendo frequentemente concomitantes e associadas a um pior prognóstico. Os profissionais de saúde devem diagnosticar e fornecer um tratamento adequado para a depressão e disfunção executiva nos primeiros três meses após o AVC. Mais estudos devem avaliar a efetividade de programas de deteç̧ão precoce e tratamento da depressão e disfunção executiva pós-AVC.

Palavras-chave: acidente vascular cerebral, depressão, comprometimento cognitivo, cognição, função executiva, testes neuropsicológicos.

\footnotetext{
${ }^{1}$ Consultation-Liaison Psychiatry Group, Department and Institute of Psychiatry, Clinics Hospital, Medical School, University of São Paulo, São Paulo SP, Brazil. ${ }^{2}$ Neurology Department, Clinics Hospital, Medical School, University of São Paulo, Teaching and Research Israeli Institute, Albert Einstein Israeli Hospital, São Paulo SP, Brazil. 'Division of Psychology, Clinics Hospital, Medical School, University of São Paulo, São Paulo SP, Brazil.
}

Luisa Terroni. Rua Dr. Ovidio Pires de Campos, 785 / $3^{\circ}$ andar / sl 13 - 05403-903 São Paulo SP - Brazil. E-mail: luterroni@gmail.com 


\section{INTRODUCTION}

epression is the most common psychiatric complicidence rates. The reported prevalence of major depression within three months after stroke ranges from $22 \%$ to $31 \% .^{1-5}$ The incidence rates of major depression after stroke (PSD) are little explored in the literature because most studies have included patients with past history of depression. ${ }^{2,6-9}$ Three studies have investigated the incidence of PSD after a stroke, Gainotti et al., reported an incidence of $27 \%$ 2-4 months after the stroke; ${ }^{10}$ Spalletta et al., found a rate of $25 \%$ between 3 weeks and 3 months after stroke, ${ }^{3}$ and Terroni et al. reported an incidence of 28.8\% 3-4 months after first stroke. ${ }^{11}$ Besides its high frequency, depression has a negative impact in the post-stroke phase. PSD, or even depressive symptoms after stroke, have been associated with increased mortality, greater impairment in physical functioning and language, longer hospitalization, reduced quality of life and cognitive impairments. ${ }^{12-14}$ Studies have supported that PSD has underlying biological and psychosocial etiologic factors such as cognitive impairment, female sex, hypercortisolism, poor social network, living alone and previous depression. ${ }^{2,6,9,15-17}$

Studies on cognitive impairment after stroke have reported rates ranging from $35.2 \%$ to $87 \% .{ }^{18-20}$ Similarly to PSD, cognitive impairment in stroke has been associated with negative outcomes such as reduced functional recovery and increased risk of mortality ${ }^{18,21-23}$ Moreover, cognitive impairment may represent a sign of changes in evolution to degenerative diseases. ${ }^{24}$ It has been reported that $55 \%$ of patients have impairment in at least one cognitive domain, ${ }^{25}$ and frontal network syndromes have been found in $51 \%$ of subjects. ${ }^{20}$ Notably, executive dysfunction has been reported to range from $18 \%$ to $40 \% .^{26-29}$

Considering the high prevalence of depression and cognitive impairment, particularly cognitive dysfunction after stroke, their negative impact on prognosis and mortality, and the fact they are comorbid, render it important to study their relationship. Thus, the aim of this study was to review the literature on the association between PSD and cognitive impairment.

\section{METHODS}

Key words used for this review were "post-stroke depression", "cognitive impairment", "cognitive dysfunction", and "neuropsychological tests". All studies in PubMed published between 2002 and 2012 retrieved based on these key words by the electronic search were reviewed for inclusion. Reference lists of studies included in the present review were also searched in order to identify additional citations. Studies in English, Portuguese, Spanish and Italian languages were included. Our target studies were original quantitative studies investigating the relationship between post-stroke depression and cognitive impairment. Inclusion criteria for the present review were as follows: [A] original quantitative study; [B] studies examining cognitive function using neuropsychological tests, not only the Mini-Mental State Examination (MMSE); $[C]$ the presence/absence of depression determined using a standardized diagnostic interview procedure or valid rating scale for depression; [D] study participants limited to stroke patients; and [E] evaluation performed within the first three months of stroke. Review articles, case reports and unpublished data were excluded. The search was limited to studies involving adult human participants.

\section{RESULTS}

The electronic search yielded forty potential studies for inclusion. Selection of studies involved initial screening of titles and abstracts to determine whether each study might meet the inclusion criteria stated above. A total of 37 studies were excluded. The reasons for exclusion were: $[\mathrm{A}]$ time period of evaluation longer than 3 months, N=5; [B] Chinese, Romanian, German, Russian, French languages, $N=7 ;[C]$ reviews, $N=5$; $[D]$ not depression and cognitive function investigation study, case report study, randomized clinical trial or no use of neuropsychological tests for cognitive evaluations, $\mathrm{N}=19$; and [E] study participants with transient ischemic attack, $\mathrm{N}=1$. Based on the stated inclusion criteria, three original quantitative studies were identified for the present review. After manual search, a further three studies were included that also met the inclusion criteria for the present review despite having been published before the previously established publication search period. The reasons behind the decision to include them were: [1] the study performed by Bolla-Wilson et al. ${ }^{30}$ was the first to use neuropsychological tests to assess cognitive function; [2] the studies of Pohjasvaara et al. ${ }^{27}$ and Vataja et al. ${ }^{31}$ included partially the same cohort of patients but given the different aims and methods employed by the two studies they were both included.

The four original quantitative studies identified for the present review, as well as the two earlier studies that used neuropsychological tests within three months of stroke, ${ }^{27,31-34}$ are listed in Table 1.

Association between post-stroke depression and cognitive impairment. Two early studies investigated the relation- 
ship between depression and cognitive domains (Table 1). The first found that patients with left hemisphere lesions and major depression performed significantly worse compared with non-depressed patients in four of nine cognitive domains. ${ }^{30}$ The authors concluded that post-stroke major depression appeared to produce a decline in cognitive performance dependent on the laterality of the lesion. Along the same lines, Kauhanen et al. ${ }^{32}$ examined 106 patients with first stroke at 1 to 7 days, 3 months and 12 months, after stroke using an extensive battery of neuropsychological tests. The presence of major depression after stroke was associated with impaired visual and verbal memory, nonverbal problem solving, attention and psychomotor speed at 12 months after stroke.

Recently, the association between depression symptomatology and cognitive impairment was investigated in 126 patients with first stroke at 3 weeks post-stroke. ${ }^{33}$ Of the included patients, $40 \%$ demonstrated mild, and $12 \%$ moderate to severe, depressive symptoms. Even after adjusting for lesion size, the neuropsychological profile of patients with moderate to severe depressive symptoms primarily showed compromise of memory, visual perception and language. A significant relationship was found in this study between severity of depressive symptoms and cognitive impairment. Patients with severe depressive symptoms had three times more cognitive impairment compared to patients with mild depressive symptoms. Interestingly, the authors suggested that depressive symptoms early after stroke are, at least in part, a reactive phenomenon secondary to severe cognitive deficits. Along the same line, Barker-Collo found that $74.6 \%$ of variance in depression after stroke was explained by significant relationships between reduced cognitive speed, poorer verbal memory, and increased impact of interference (Stroop ratio) besides other factors. Cognitive performance explained the greatest proportion of variance, $51.3 \%$, in depression. The author concluded that "The findings suggest that cognition and mood are linked over and above physical independence and that both should be addressed as part of the rehabilitative process". ${ }^{34}$

Pohjasvaara et al. initially published a study that included 256 patients, aged 55-85 years, evaluating patients 3 and 4 months after stroke. The authors reported that $40.6 \%(\mathrm{~N}=104)$ of patients had executive dysfunction. Also, executive dysfunction was shown to be associated with depression symptoms. ${ }^{27}$ Recently, Vataja et al. described the depression-executive dysfunction syndrome after stroke. These authors reported that patients with depression-executive dysfunction had more severe depressive symptoms. Three months after ischemic stroke, brain infarcts affecting the frontal-subcortical circuit structures were significantly more frequent in patients with depression-executive dysfunction than in post-stroke subjects without depression-executive dysfunction. ${ }^{31}$

\section{DISCUSSION}

The early studies assessing cognitive function using neuropsychological tests in the first three months after stroke reported associations between specific neuropsychological profiles and depression. Impairment in orientation, language, executive/motor function, memory, attention and psychomotor speed have been associated with depression..$^{30,32}$ More recently, executive function impairment has been associated with depression after stroke and some authors have considered the existence of depression-dysexecutive syndrome within three to four months of stroke. ${ }^{27,31}$ Depression-executive dysfunction syndrome has been defined as late-onset depression associated with executive dysfunction..$^{35}$ The executive function refers to a set of complex functions some of which include initiation / volition, planning, survey hypotheses, flexibility of thought, decision making, self-regulation, judgment, use of feedback and selfperception, amongst others.

Other studies have described the association between severity of PSD and magnitude of cognitive deficits. ${ }^{32}$ Cognitive impairment was shown to be three times more frequent in patients with more severe depression compared to those with mild symptoms. ${ }^{33}$ In addition, depression was more intense in patients with depression-executive dysfunction than in those without. ${ }^{31}$

Some studies have found that cognitive impairment after stroke is an important predictor of long-term depressive symptoms. ${ }^{34}$ The prognostic value of cognition suggests a reactive component in the development or continuation of long-term depressive symptoms. ${ }^{36}$ On this matter, some authors have proposed that depressive symptoms are, at least in part, a secondary reaction to cognitive deficits in post-stroke patients ${ }^{32,37}$ although the subject remains controversial. Studies evaluating the effects of treatment of depression on cognitive function have yielded some contributions to this question.

Treatment of PSD has been associated with cognitive improvement suggesting that cognitive impairment is a symptom or consequence of depression..$^{38-42}$ For instance, Narushima et al. ${ }^{43}$ reported that in patients with early and sustained remission of depression there was a rapid improvement in cognitive function and this improvement persisted over a 2-year period. Further- 
Table 1. Studies investigating the association between depression and cognitive function within three months of stroke.

\begin{tabular}{llll}
\hline Study & Characteristics of patients & $\begin{array}{l}\text { Neuropsychological tests and type of cognitive } \\
\text { impairment associated with depression }\end{array}$ & Depression evaluation \\
\hline Bolla-Wilson et al. & $<60$ days, $\mathrm{N}=53$ & $\begin{array}{l}\text { Tests: Boston Naming Test, Reciting of Months Forward, DSM-III } \\
(1989)^{30}\end{array}$ & $\begin{array}{l}\text { Repetition of Words and Phrases, Verbal Fluency, Com- } \\
\text { Cross-sectional }\end{array}$ \\
& $\begin{array}{l}\text { prehension of Complex Ideational Material, Logical mem- had major depression } \\
\text { ory - immediate and delayed recall, Recurrent Words, Digit }\end{array}$ \\
& Span, Visual Reproduction, Recurrent words, Logical memory, \\
& Rey Auditory Verbal Learning test, Visual Reproduction, Block \\
& Design, Clock Drawing Test, Hooper Visual Organization Test, \\
& Verbal fluency for a single letter and animals, Alternating Fin- \\
& gers, Luria Motor Sequences. \\
& Findings: impairment in orientation, language, executive/mo- \\
& tor function.
\end{tabular}

\begin{tabular}{ll}
\hline Kauhanen et al. & $1-7$ days, $N=106$ \\
$(1999)^{32}$ & 3 months, $N=101$ \\
& First stroke \\
& Follow-up study
\end{tabular}

Tests: 5 subtests of the Wechsler Adult Intelligence Scale-Re- DSM III-R

vised, subtests of the Wechsler Memory Scale, serial learning $53 \%$ depressed at 3 months

and interference tasks, and visual recognition memory task, 9\% major depression

Trail-Making Test A, Verbal Fluency, copying tasks and modi- 44\% minor depression

fied clock hand task.

Findings: visual and verbal memory, nonverbal problem solv-

ing, attention and psychomotor speed.

\begin{tabular}{|c|c|c|c|}
\hline $\begin{array}{l}\text { Pohjasvaara et al. } \\
(2002)^{27 \star}\end{array}$ & $\begin{array}{l}\text { 3-4 months } \\
\mathrm{N}=256 \text { patients } \\
\mathrm{N}=37 \text { controls } \\
\text { Cross-sectional cohort study }\end{array}$ & $\begin{array}{l}\text { Tests: Wisconsin Card Sorting Test, Trail Making test, Stroop } \\
\text { test, Verbal Fluency. } \\
\text { Finding: executive dysfunction. }\end{array}$ & BDI \\
\hline $\begin{array}{l}\text { Nys et al. } \\
(2005)^{33 *}\end{array}$ & $\begin{array}{l}3 \text { weeks } \\
\mathrm{N}=126 \text { patients with first stroke } \\
\mathrm{N}=87 \text { controls } \\
\text { Cross-sectional study }\end{array}$ & $\begin{array}{l}\text { Tests: Raven Advanced Progressive Matrices; Rey Auditory } \\
\text { Verbal Learning Test and Rey-Osterrieth Complex Figure-De- } \\
\text { lay; Brixton Spatial Anticipation Test; Test of Everyday Atten- } \\
\text { tion; Judgment of Line Orientation; Test of Facial Recognition; } \\
\text { Digit Span; Token test; Boston Naming Test. } \\
\text { Findings: domain of memory, visual perception and language. }\end{array}$ & $\begin{array}{l}\text { MADRS } \\
40 \% \text { mild depressive symptoms } \\
12 \% \text { moderate/severe depres- } \\
\text { sive symptoms }\end{array}$ \\
\hline $\begin{array}{l}\text { Vataja et al. } \\
(2005)^{31 \star \#}\end{array}$ & $\begin{array}{l}3 \text { months } \\
\mathrm{N}=158 \text { patients } \\
\mathrm{N}=28 \text { controls } \\
\text { Cross-sectional } \\
\text { Cohort study }\end{array}$ & $\begin{array}{l}\text { Tests: Nelson's version of the Wisconsin Card Sorting Test, } \\
\text { Stroop test, Trail-Making A and B tests, Verbal fluency. } \\
\text { Findings: } 33.5 \% \text { of patients with executive dysfunction and } \\
13.3 \% \text { with depression-dysexecutive syndrome. }\end{array}$ & $\begin{array}{l}\text { SCAN } \\
\text { MADRS } \\
39.2 \% \text { depressed patients }\end{array}$ \\
\hline $\begin{array}{l}\text { Barker-Collo } \\
(2007)^{34}\end{array}$ & $\begin{array}{l}3 \text { months } \\
\mathrm{N}=73 \text { patients } \\
\text { First stroke } \\
\text { Cross-sectional study }\end{array}$ & $\begin{array}{l}\text { Tests: CVLT-II, VPA, IVA-CPT, Digit and spatial spans, Victoria } \\
\text { Stroop. } \\
\text { Findings: reduced cognitive speed, poorer verbal memory, and } \\
\text { increased impact of interference (Stroop ratio). }\end{array}$ & $\begin{array}{l}\text { BDI } \\
22.8 \% \text { moderate or severe de- } \\
\text { pression }\end{array}$ \\
\hline
\end{tabular}

*Findings in the electronic search of PubMed; \#study sample was part of study sample of Pohjasvaara et al. (2002) but not the same patients. In study by Vataja et al. (2005), authors included only those patients who did not fulfill the DSM-III criteria for dementia and had psychiatric examination; LH: left hemisphere; RH: right hemisphere; CVLT-II: California Verbal Learning Test-Il; VPA:Visual Paired Associates; IVA-CPT: Integrated Visual Auditory Continuous Performance Test; MADRS: Montgomery Asberg Depression Rating Scale; BDI: Beck Depression Inventory; SCAN: Schedules for Clinical Assessment in Neuropsychiatry; DSM III- R: Diagnostic and Statistical Manual of Mental Disorders, Revised, $3{ }^{\text {rd }}$ edition.

more, cognitive function remained unchanged in nondepressed patients over a 2-year follow-up. Even when only mood was considered, patients with post-stroke major depression whose mood improved at follow-up had significantly greater recovery in cognitive function than patients whose mood did not improve. ${ }^{44}$ Amelioration of depressive symptoms and cognitive impairment was described after anodal stimulation to the left dorsolateral prefrontal cortex (DLPFC). ${ }^{40}$ In this case report, it was not possible to conclude whether the improve- ment in cognitive function was secondary to depression improvement or whether the effects were independent of each other. On the other hand, improvement in global cognitive function, specifically in verbal and visual memory functions, was found to be independent of effects on depression after treatment with escitalopram in a randomized trial..$^{45}$ Therefore, we conclude that the beneficial effect of treatment of depression in the process of cognitive post-stroke recovery should be further investigated by prospective studies and clinical trials. 
Although treatment of depression is effective and can be associated with cognitive recovery, underdiagnosis of PSD and cognitive disorders after stroke has been reported. Depression may be diagnosed in only $20 \%$ to $50 \%$ of depressed stroke patients. ${ }^{46}$ Cognitive impairments are often inaccurately diagnosed. After applying a screening battery of tests for cognitive evaluation, thirty-five percent of patients was found to have more cognitive impairments than previously diagnosed by the assisting treatment team. ${ }^{47}$ It should be remembered that programs of cognitive rehabilitation have been proven to be effective. ${ }^{48}$ These findings, combined with high prevalence rates of depression and cognitive impairment, support the need for programs that include interventions to treat both stroke complications, particularly those evaluating the prognostic usefulness and efficacy of treatment over the long-term. ${ }^{21}$

From a clinical perspective, knowing which patients are at increased risk of developing PSD associated with cognitive impairment may ameliorate prevention, detection, and early treatment of both conditions, consequently reducing their negative impact on recovery. Both depression and cognitive impairment are associ- ated with worse stroke outcomes. ${ }^{23,27,49,50}$ In particular, impairment of executive function is a robust predictor of poor functional recovery after stroke. ${ }^{27,29}$ The depression-executive dysfunction syndrome is a stronger predictor of poor long-term survival than depression itself. Patients with both depression and executive dysfunction have shorter median survival than patients with neither depression nor executive dysfunction ( 6.6 versus 10.3 years) ${ }^{51}$

In conclusion, the present review suggests that the association between depression and cognitive impairment in the first three months after stroke is frequent and often underdiagnosed. Based on the current state of knowledge on the association between depression and cognitive impairment after stroke, we propose the following plan of action: (a) Implementation of programs to increase diagnosis and treatment of PSD by non-psychiatrist physicians; (b) Monitoring and evaluation of programs that include identification and interventions related to cognitive impairment; (c) Definition of executive dysfunction as a possible element of a depressive syndrome or a predictor of PSD.

\section{REFERENCES}

1. Robinson RG, Starr LB, Lipsey JR, et al. A two-year longitudinal study of post-stroke mood disorders: dynamic changes in associated variables over the first six months of follow-up. Stroke 1984;15:510-517.

2. Astrom M, Adolfsson R, Asplund K. Major depression in stroke patients. A 3-year longitudinal study. Stroke 1993;24:976-982.

3. Spalletta G, Ripa A, Caltagirone C. Symptom profile of DSM-IV major and minor depressive disorders in first-ever stroke patients. Am J Geriatr Psychiatry 2005;13:108-115.

4. Terroni L, Leite CC, Tinone G, et al. [Poststroke depression: risk factors and antidepressant treatment]. Rev Assoc Med Bras 2003;49:450-459.

5. Hackett ML, Anderson CS. Frequency, management, and predictors of abnormal mood after stroke: the Auckland Regional Community Stroke (ARCOS) study, 2002 to 2003. Stroke 2006;37:2123-2128.

6. Vataja R, Pohjasvaara T, Leppavuori A, et al. Magnetic resonance imaging correlates of depression after ischemic stroke. Arch Gen Psychiatry 2001;58:925-931.

7. Aben I, Verhey F, Strik J, et al. A comparative study into the one year cumulative incidence of depression after stroke and myocardial infarction. J Neurol Neurosurg Psychiatry 2003;74:581-585.

8. Robinson RG, Price TR. Post-stroke depressive disorders: a follow-up study of 103 patients. Stroke 1982;13:635-641.

9. Provinciali L, Paolucci S, Torta R, et al. Depression after first-ever ischemic stroke: the prognostic role of neuroanatomic subtypes in clinical practice. Cerebrovasc Dis 2008;26:592-599.

10. Gainotti G, Azzoni A, Marra C. Frequency, phenomenology and anatomical-clinical correlates of major post-stroke depression. Br J Psychiatry 1999;175:163-167.

11. Terroni L, Fraguas R, Lucia M, et al. Importance of retardation and fatigue/interest domains for the diagnosis of major depressive episode after stroke: a four months prospective study. Rev Bras Psiquiatr 2009; 31:202-207.

12. Parikh RM, Robinson RG, Lipsey JR, et al. The impact of poststroke depression on recovery in activities of daily living over a 2-year followup. Arch Neurol 1990;47:785-789.
13. Burvill PW, Johnson AK, Jamrozik KD, et al. Prevalence of Depression After Stroke: The Perth Community Stroke Study. Br J Psychiatry 1995; 166:320-327.

14. King RB. Quality of life after stroke. Stroke 1996;27:1467-1472.

15. Andersen G, Vestergaard K, Ingemann-Nielsen M, et al. Risk factors for post-stroke depression. Acta Psychiatr Scand 1995;92:193-198.

16. Robinson RG, Kubos KL, Starr LB, et al. Mood disorders in stroke patients. Importance of location of lesion. Brain 1984;107 (Pt 1):81-93.

17. Aben I, Verhey F. Depression after a cerebrovascular accident. The importance of the integration of neurobiological and psychosocial pathogenic models. Panminerva Med 2006;48:49-57.

18. Tatemichi TK, Desmond DW, Stern Y, et al. Cognitive impairment after stroke: frequency, patterns, and relationship to functional abilities. J Neurol Neurosurg Psychiatry 1994;57:202-207.

19. Hoffmann M. Stroke in the young: The multiethnic prospective durban stroke data bank results. J Stroke Cerebrovasc Dis 1998;7:404-413.

20. Hoffmann M, Schmitt F, Bromley E. Vascular cognitive syndromes: relation to stroke etiology and topography. Acta Neurol Scand 2009; 120:161-169.

21. Barker-Collo S, Feigin V. The impact of neuropsychological deficits on functional stroke outcomes. Neuropsychol Rev 2006;16:53-64.

22. Farner L, Wagle J, Engedal K, et al. Depressive symptoms in stroke patients: a 13 month follow-up study of patients referred to a rehabilitation unit. J Affect Disord 2010;127:211-218.

23. Hobson P, Meara J. Cognitive function and mortality in a communitybased elderly cohort of first-ever stroke survivors and control subjects. J Stroke Cerebrovasc Dis 2010;19:382-387.

24. O'Brien JT, Erkinjuntti T, Reisberg B, et al. Vascular cognitive impairment. Lancet Neurol 2003;2:89-98.

25. Madureira S, Guerreiro M, Ferro JM. Dementia and cognitive impairment three months after stroke. Eur J Neurol 2001;8:621-627.

26. Nys GM, van Zandvoort MJ, de Kort PL, et al. Cognitive disorders in acute stroke: prevalence and clinical determinants. Cerebrovasc Dis 2007;23:408-416. 
27. Pohjasvaara T, Leskela M, Vataja R, et al. Post-stroke depression, executive dysfunction and functional outcome. Eur J Neurol 2002;9:269-275.

28. Ballard C, Stephens S, Kenny R, et al. Profile of neuropsychological deficits in older stroke survivors without dementia. Dement Geriatr Cogn Disord 2003:16:52-56.

29. Lesniak M, Bak T, Czepiel W, et al. Frequency and prognostic value of cognitive disorders in stroke patients. Dement Geriatr Cogn Disord 2008;26:356-363.

30. Bolla-WilsonK, RobinsonRG, Starkstein SE, etal. Lateralization of dementia of depression in stroke patients. Am J Psychiatry 1989;146:627-634.

31. Vataja R, Pohjasvaara T, Mantyla R, et al. Depression-executive dys function syndrome in stroke patients. Am J Geriatr Psychiatry 2005; 13:99-107.

32. Kauhanen M, Korpelainen JT, Hiltunen P, et al. Poststroke depression correlates with cognitive impairment and neurological deficits. Stroke 1999;30:1875-1880

33. Nys GM, van Zandvoort MJ, van der Worp HB, et al. Early depressive symptoms after stroke: neuropsychological correlates and lesion characteristics. J Neurol Sci 2005;228:27-33.

34. Barker-Collo SL. Depression and anxiety 3 months post stroke: prevalence and correlates. Arch Clin Neuropsychol 2007;22:519-531.

35. Alexopoulos GS, Meyers BS, Young RC, et al. Clinically defined vascular depression. Am J Psychiatry 1997;154:562-565.

36. Nys GM, van Zandvoort MJ, van der Worp HB, et al. Early cognitive impairment predicts long-term depressive symptoms and quality of life after stroke. J Neurol Sci 2006;247:149-156.

37. Verdelho A, Henon $\mathrm{H}$, Lebert $\mathrm{F}$, et al. Depressive symptoms after stroke and relationship with dementia: A three-year follow-up study. Neurology 2004;62:905-911.

38. Kimura M, Robinson RG, Kosier JT. Treatment of cognitive impairment after poststroke depression: a double-blind treatment trial. Stroke 2000; 31:1482-1486

39. Simis S, Nitrini R. Cognitive improvement after treatment of depressive symptoms in the acute phase of stroke. Arq Neuropsiquiatr 2006;64:412-417.
40. Bueno VF, Brunoni AR, Boggio PS, et al. Mood and cognitive effects of transcranial direct current stimulation in post-stroke depression. Neurocase 2011;17:318-322.

41. Sato S, Yamakawa Y, Terashima Y, et al. Efficacy of milnacipran on cognitive dysfunction with post-stroke depression: preliminary open-label study. Psychiatry Clin Neurosci 2006;60:584-589.

42. Spalletta G, Guida G, Caltagirone C. Is left stroke a risk-factor for selective serotonin reuptake inhibitor antidepressant treatment resistance? J Neurol 2003;250:449-455

43. Narushima K, Chan KL, Kosier JT, et al. Does cognitive recovery after treatment of poststroke depression last? A 2-year follow-up of cognitive function associated with poststroke depression. Am J Psychiatry 2003;160:1157-1162.

44. Murata Y, Kimura M, Robinson RG. Does cognitive impairment cause post-stroke depression? Am J Geriatr Psychiatry 2000;8:310-317.

45. Jorge RE, Acion L, Moser D, et al. Escitalopram and enhancement of cognitive recovery following stroke. Arch Gen Psychiatry 2010;67: 187-196.

46. Schubert DS, Taylor C, Lee S, et al. Detection of depression in the stroke patient. Psychosomatics 1992;33:290-294.

47. Edwards DF, Hahn MG, Baum CM, et al. Screening patients with stroke for rehabilitation needs: validation of the post-stroke rehabilitation guidelines. Neurorehabil Neural Repair 2006;20:42-48.

48. Miotto EC, Sato J, Lucia MC, et al. Development of an adapted version of the Boston Naming Test for Portuguese speakers. Rev Bras Psiquiatr 2010;32:279-282.

49. Zhou B, Zhao Q, Teramukai S, et al. Executive function predicts survival in Alzheimer disease: a study in Shanghai. J Alzheimers Dis 2010;22:673-682.

50. Johnson JK, Lui LY, Yaffe K. Executive function, more than global cog nition, predicts functional decline and mortality in elderly women. $J$ Gerontol A Biol Sci Med Sci 2007;62:1134-1141.

51. Melkas S, Vataja R, Oksala NK, et al. Depression-executive dysfunction syndrome relates to poor poststroke survival. Am J Geriatr Psychiatry 2010;18:1007-1016. 